\title{
TRANSMISSION OF TEXTS AND NEW TECHNOLOGIES: MEMORY OR TRANSFORMATION?
}

JOANNA PIETRZAK-THÉBAULT Wydział Nauk Humanistycznych Uniwersytetu Kardynała Stefana Wyszyńskiego; Faculty of Humanities Cardinal Stefan Wyszyński University in Warsaw (Poland) jptwaleczna@gmail.com

The ways in which the written texts were transmitted used to evolve through the history. Nowadays, the process is particularly quick and multi-directional. Many new media coexist. Some of them, that we still remember very well, such as recording tapes and cassette tape recorders, as well as PC discs, soft and hard, and many of PC programs themselves have had completely disappeared or have changed so much that it is quite impossible to read what we recorded less than twenty years ago. We know that there are pendrives, audiobooks, e-books, e-readers, iPads, iMacs, tablets, laptops, PC connected to the Web and we also know that there will appear new devices to communicate and to get connected, probably very soon. It is but a cliché to say that a large part of the science, humanities included, is being technologically virtualized ${ }^{1}$. We are here, however, interested in transmission of texts, and mostly the literary ones. The Internet brings also practical and institutional changes to education, teaching and scientific work in the field of humanities. Such undertakings as the DPLA (Digital Public Library of America) or the digital library 'Europeana' are capable of rising enthusiastic reactions. When speaking about new digital technologies and their use, quite exclusively technical or economical aspects are taken into consideration

${ }^{1}$ See magazines such as „Digital Humanities Quarterly”, http://digitalhumanities. org/dhq/vol/1/index.htlm, published since 2007. 
and how rarely the reflection goes also to the logic of the transmission of documents imposed by these new methods. Documents, both simply digitalized or being subject to different processes, which remain invisible for users (cuts, shortenings, contaminations and so on). These changes to come (or already in progress) seem in fact much more significant than eventual similar changes of ways of communication that apparently took place in society at the turn of manuscript/print epoch, as Marshall McLuhan would like to consider ${ }^{2}$. These works are quite advanced and they will be continued - the way is clearly traced out ${ }^{3}$. Some examples of a serious reflexion about the digital form of textual criticism and editorial scholarship appeared recently ${ }^{4}$. One of them is a progressing standardization and the conviction that it is a right way to proceed ${ }^{5}$. Nowadays, the role of new technologies in textual transmission is far from being clear and it is difficult not to agree with Peter Shillinsburg when he says that 'the advent of digital technologies for preservation and dissemination of texts has complicated rather than revolutionized textual scholarship on literary texts ${ }^{6}$.

${ }^{2}$ See M. McLuhan, The Gutenberg Galaxy, Toronto 1962, passim and, for actualization of his point of view N. Harris, Con piede sbagliato, e con I piedi di piombo, „Ecdotica” 2014, № 11, p.73-74.

${ }^{\mathrm{See}} \mathrm{H}$. Besser, The Past, Present, and Future of Digital Libraries, [in:] A Companion to Digital Humanities, ed. S. Schreibmanm, R. Siemens, J. Unsworth, Oxford 2004 (http://www.digitalhumanities.org/companion), chap. 36. See also a new interactive website of the Polish National Library „Polona”, http://www.polona.pl/. Cf. A. Serrai, Google e bibliografia, „Bibliotheca” 2007, № 2, pp. 18-22.

${ }^{3}$ J. McGann, Philology in a New Key, ,Chicago Journals” 2013, № 39/2 (Winter) (http://www.jstor.org/stable/10.1086/668528), p. 327.

${ }^{4}$ M. Byron, Archive, Text, Screen: Remediations of Modernist Manuscripts, „Ecdotica” 2014, № 14, pp. 56-71. It is very inspiring and instructive indeed, and it offers also an interesting bibliography on the subject.

${ }^{5}$ G. C. Bowker, Memory Practices in the Sciences, Cambridge MA - London 2005, p. 8-9.

${ }^{6}$ P. Shillinsburg, Literary Documents, Texts, and Works Represented Digitally, „Ecdotica” 2013, № 10, s. 76. See also M. Zaccarello about J. McGann, L'edizione critica nella nuova 'repubblica delle lettere', „Ecdotica” 2014, № 11, p. 18. 
We can also notice a temptation to understand and to determine, which content of ancient documents and texts is worth preserving ${ }^{7}$. At the same time, however, some scholars persist in believing that paper book is irreplaceable as it includes a dynamic and potential of communication and consists a 'feast' for readers' eyes as well. So, even an apparently paradoxical thesis is presented: 'If a paper book had been invented after an e-book, it would have been considered as a progress' ${ }^{8}$. Two questions should be asked nowadays: what shall we do with the digitalized substitutes, what use them for? When all books will be digitalized (it is still a theory) - real books, as objects, will still exist ${ }^{9}$. The second question seems today even more important: how to select documents we want to digitalize? Who will decide that, for example, astrology or languages that are not spoken anymore or those slowly disappearing are not (and will never be) of any use neither interest for us ${ }^{10}$ ?

${ }^{7}$ J. McGann, op. cit., p. 340. 15 millions of digitalized books by Google should consist of only $12 \%$ of all titles existing in the world. See also R. Bomba, Narzędzia cyfrowe jako wyznaczniki nowego paradygmatu badań humanistycznych, [in:] Zwrot cyfrowy w humanistyce, op. cit., p. 61.

${ }^{8}$ H. Tuzzi (A. Bon), Libro antico libro moderno. Per una storia comparata, Milano 2006. Here: F. Sabba, „Bibliotheca” 2006, № 2, pp. 235-236. Since 2012 there have been published by Johns Hopkins University Press a Digital Philology. Journal of Medieval Cultures, entirely dedicated to the new possibilities and research perspectives offered by the digitalization and work in the Web. In Poland see published recently Ł. Bolikowski, J. Kozłowski, Ekspansywna hybryda. Narodziny i dojrzewanie humanistyki cyfrowej, „Z badań nad książką i księgozbiorami historycznymi” 2012, vol. 6, pp. 181-188. See also other articles entitled Platforma cyfrowa dziejów ksiązki and Zwrot cyfrowy w humanistyce, ed. A. Radomski, E. Bomba, Lublin 2013 (http://e-naukowiec.eu/wp-content/uploads/2013/05/Zwrot_cyfrowy_w_humanistyce.pdf); and in particular the editorial Internet, nowe media, kultura, p. 7, 9.

${ }^{9}$ Cf. M. Deegan, S. Tanner, Conversion of Primary Sources, [in:] A Companion to Digital Humanities, op. cit., chap. 32; A. Tara Walker, The Boundless Book: A Conversation between the Pre-modern and Post-human, „Digital Humanities Quarterly” 2013, vol. 7, № 1.

${ }^{10}$ J. McGann, op. cit., p. 334. 
The appearance of the Internet reality is a real challenge for humanities, and for philology in particular ${ }^{11}$.

New technologies put transmitting and preserving texts in the face of new challenges. Jerome McGann recalls the example of the Library of Alexandria which, as 'the library of libraries' consisted the original model of the modern 'net'. Taking into account differences of technologies it was a manifestation of the same ambition: to gather at one place all manuscripts, written in all languages, also those that at the time were remote or dead. The digitalization, advancing as a snowball seems, in a common opinion, to call in question the method of exploring the sources. A new and unparalleled any time before, easy access to the content (and to the image) of the manuscripts and early printed books, leads to a peculiar revel in new possibilities and to treat this situation as completely exceptional. But at the same time a similar change of a leading medium of transmission occurred already once in the history of the European culture. It happened when a printing press, using mobile types, was invented and spread. Its popularization led to huge changes in the canon of texts that were read and reproduced, and also brought about new contexts and situations of communication. Usually we focus on the positive aspects of this change, but a deeper analysis may let us see also a price that should be paid, linked with the process of selection and forgetting. Maybe we will find there some resemblances. I want to recall what could help us to understand how new technologies function when they transmit knowledge, cultural heritage, and $\operatorname{art}^{12}$.

As a matter of fact, these changes were arriving step by step. New ways of transmission were truly based on the traditional ones, and for a certain

${ }^{11}$ Ibidem, p. 328.

${ }^{12}$ N. Harris (op. cit., p. 77) speaks even about a 'deja vu'! 
time both ways of transmission coexisted ${ }^{13}$. Awareness of these facts may be very helpful indeed to appreciate the modern changes as well as to try to foresee their directions. It could also lead to a certain relativisation of what is actually happening ${ }^{14}$.

The invention of printing appeared during the time of big technological discoveries in the field of metallurgy, simultaneously to the beginnings of the artillery and to the origins of engineering. Weighty changes in a field of communication's technics never appear isolated from new technologies that are invented in other fields. When more than 500 years ago reading (and, as we will see, also non-reading) social circles were suddenly confronted to the possibilities that increased in an unimaginable extent in scope of the reproduction of texts, they were obliged, as we are today, to re-define their relations to the text itself ${ }^{15}$. When Cosimo de Medici the Elder in the '50 of the $15^{\text {th }}$ century founded, for him and for his beloved son Giovanni, a library in Fiesole, in the nearby of Florence, he employed 45 scribes to copy 200 manuscripts. In the same time, printed books just started to appear and only in this first period, usually counted until 1501, when prints used to 'learn' everything, just like newborn babies laying in a cradle (in cunabula), around 27000 editions can be counted (and 12000 of them on the Apennines Peninsula, making 45\%). This estimation accounts for, of course, only editions that survived at least in one copy. We will never be perfectly sure of how many of them have completely disappeared (specialists speak about as much as $1 / 3$ of this production that has not survived up to our days $)^{16}$. It was

${ }^{13} \mathrm{Cf}$. W. Von Stromer, Au berceau des médias de masse: l'invention de l'impression des textes et des images [in:] Le berceau du livre: autour des incunables, éd. F. Barbier, Bordeaux 2003, pp. 9-24.

${ }^{14}$ Cf. M. Byron, op. cit., p. 59.

${ }^{15}$ Cf. P. Celiński, Renensansowe korzenie cyfrowego zwrotu, [in:] Zwrot cyfrowy w humanistyce, op. cit., pp. 18-19 \& 27; A. Tara Walker, op. cit.

${ }^{16}$ Bibliography on the subject is extremely rich, but unfortunately there are only few books concerning the beginnings of printing that are available in Polish. See 
probably an amount of 10 millions of books that appeared in Europe, where used to live no more than 100 millions of inhabitants. And surely not more than few hundreds of thousands of them could really read ${ }^{17}$. The change took place in a relatively short time, in memory of only two generations. If we consider that people used to feel the time passing much slower than nowadays, that rate was really rapid, may be even considered as shocking ${ }^{18}$.

Incunabula - the book children - used to learn, of course, from the only teacher they knew - the manuscript ${ }^{19}$. During the early years of print both practices used to function side by side. New forms didn't see, for example, why not to begin a text, as it used to be in all manuscripts, by an incipit and a title page in fact did not appear for quite a long time ${ }^{20}$. The history of shaping of a new form of a book - a modern one, the one which would persist for next 500 years without any important modifications - is not only fascinating; it is also instructive, because it proves how long the elaboration of the autonomy of a new medium can last ${ }^{21}$. One of the most spectacular

E. Eisenstein, Rewolucja Gutenberga, transl. H. Hollender, Warszawa 2004 (the first Cambridge edition of The Printing Revolution in Early Modern Europe is from 1983!) and H.J. Martin, L. Febvre, Narodziny książki, transl. P. Rodak, Warszawa 2014 (L'apparition du livre, Paris 1958).

${ }^{17}$ H.J. Martin, Histoire et pouvoirs de l'écrit, Paris 1988, pp. 217-218.

${ }^{18}$ Cf. J. Kula, Zegarek historyka, Warszawa 2001, pp. 154-156.

${ }^{19}$ The most complete catalogue of world fund of 15th century prints is ISTC (Incunabula Short Title Catalogue), http://www.istc.bl.uk. For Polish prints see Incunabula quae in bibliothecis Poloniae asservantur, Ossolineum, Wrocław 19701993. See also the initiative of Consortium of European Research Libraries (CERL) - its on-line catalogue of the editions up to 1830, entitled Heritage of the Printed Book Database.

${ }^{20}$ Its form has been crated not earlier than in the half of the 16th century. Cf. L'histoire de l'édition Française, ed. R. Chartier, H.J. Martin, Paris 1989, vol. 1 (1st edition 1982), p. 230. About the shaping of the title page see M. Smith, The Title Page, its Early Development, 1460-1510, London-New Castle 2000, L. Baldacchini, Aspettando il frontespizio: pagine bianche, occhietti e colophon nel libro antico, Milano 2004.

${ }^{21}$ Cf. E. Potkowski, Rękopis a druk-przełom $w$ dziejach techniki czy $w$ dziejach 
examples is a couple of missals from Lyons, both from the same 1482 year. One of them is the manuscript, the other one - printed by Neumeister. Both are illuminated by the same artist and both belonged to the same person, a canon. Until today the manuscript and the printed copy remain quite impossible to distinguish ${ }^{22}$. Even as late as in the $18^{\text {th }}$ century, we can still come across some manuscript books - just copied from the printed ones. Ivon de Fou, an aristocrat living in the nearby of Poitiers, ordered a manuscript book, an identical copy (a colophone included!) of the print from Lyons, probably of 1486 - De proprietatibus rerum written by Bartholomew the English. It is just an example, as good as could be many others. There were also plenty of cases where printed texts were decorated by manuscript initials or 'pied de mouches', used to sign the end of a paragraph. (These 'pied de mouches' still persist on screens of our computers.)

Est virgo haec penna, meretrix est stampificata - tried to convince Venetian authorities father Filippo di Strata. The majority agreed with him, even though the Venetian Republic prepared already to win the book markets of the half of the world at the time ${ }^{23}$. The opinion of the Dominican about new technology based on detailed and logical argumentation: the print is responsible for spoiling texts, they are spread much too rapidly and too many mistakes persist, as new editions are produced only for profit purposes. Many of them can also be harmful for the readers, being both immoral and heterodox. Texts that cannot be controlled by the spiritual authorities become easily available. The true and virtuous knowledge is spoiled and humiliated just because offered to the ignorants. A glance on shelves of the monastery's library in

cywilizacji, [in:] idem, Książka i pismo w średniowieczu, Pułtusk 2006, pp. 362-371 (with an interesting bibliography).

${ }^{22}$ See H.J. Martin, op. cit., p. 221.

${ }^{23}$ M. Lowry, Il mondo di Aldo Manuzio. Affari e cultura nella Venezia del Rinascimento, transl. P. Pavanini, Roma 2000, p. 75. Also p. 47, 51, 64. What can be interesting, di Strata belonged to the same cultural circles as enthusiasts of the new technology. 
Citeaux seems to prove that father Filippo was right. In 1480 there were 1245 manuscripts and in 1506 they were in number of 1788, and only 3 books were printed. But for the orders of mendicanti, brothers and fathers who used to travel a lot, the new technology appeared soon to be of a great use. They could easily take a few books with them and have them always at hand. Many doubles that persist in libraries of Dominican and Franciscan orders confirm the useful and practical character of these libraries ${ }^{24}$. The fact that manuscripts were still commonly used might have been for father Filippo a kind of consolation...

When the print appeared, the intellectual life and manuscript practices developed in isolated micro-circles and one could expect that the situation would continue. Within 1465-1467 German printers, Conrad Sweynheym \& Arnold Pannartz created a kind of a print scriptorium and printed 4 books for the first time outside Germany, in the Benedictine monastery $100 \mathrm{~km}$ distant from Rome, in Subiaco (where many German monks lived and where they arrived probably invited by the German cardinal, Nicolas de Cusa). These books were: a Latin grammar, De oratore by Cicero and two Christian authors: Lactance and St. Augustinus ${ }^{25}$. In this way, Sweynheym \& Pannartz opened the way both to the new canon of books and to the more universal dimension of the new technology and a new culture. The monastery scriptorium will appear however very soon an improper place to print, and German masters will transfer to Rome where, up to 1473, they will print 48 more books. In that time quite every single Italian town desired its own printing press - a technological novelty and very probably a hallmark of prestige, as well as a source of the anticipated income. At the end of the $15^{\text {th }}$ century

${ }^{24}$ H.J. Martin, op. cit., p. 183, 184. 40\% of the production of the printing presses in the $15^{\text {th }}$ century were works of authors coming from Franciscan and Dominican orders. M. Lowry, op. cit., p. 52.

${ }^{25}$ About first books printed on the Appenin Penisula see G.P. Carosi, Da Magonza a Subiaco, l'introduzione della stampa in Italia, Bramante, Busto Arsizio 1982. 
as many as 80 Italian towns possessed their presses. They became 250 in the whole Europe up to $1501^{26}$. However, the disappointment became very soon stronger than the pride of technological novelty: local ambitions were too exuberant and the majority of centers did simply not know what and for whom to print, so they would close their door for ever and disappear. Only those which knew, and also could find and afterwards attach quite a large public of readers, would continue to work. The first, and to some extent also the second generation of printers, came to Italy from outside - from Germany. They were mostly representatives of craftsman circles: goldsmiths, illuminators, teachers of calligraphy at best. They possessed technical skills and they thought as the 'technicians' do. The crisis that stroke the printing press after first dozens of years of its development was the effect of the lack of a larger vision, perspective how to spread, and of the limited invention and imagination. It was quite a different thing, indeed, to fill the cases by lead types and to print them on a sheet of paper than to mould a new cannon, despite using the same cast technology. This situation seems strangely appeal to our modern experience when technicians - information technologists - decide in a great extent about what is in digitalization and in electronic edition possible, desirable - and what is not. Will technicians decide, in the same way, which documents are important and therefore should be preserved and which

${ }^{26}$ H.J. Martin, op. cit., p. 217. Cf. Ph. Nieto, Géographie des impressions européennes du XV siècle, [in:] Le berceau du livre..., op. cit., pp. 125-174. See also very interesting maps showing the spread of printing activity. In Poland in the $15^{\text {th }}$ century there are 7 printing presses (3 in Cracow, 1 in Wrocław, 1 in Chełmn (?), 1 in Gdańsk and 1 ,ephemeral”, set up only for the needs of the beatification process of Dorota from Mątowy). See Drukarze dawnej Polski od XV do XVIII wieku, ed. A. Kawecka-Gryczowa, vol. 1: Małopolska, Wrocław 1983, pp. 25-39, 116, 139140, 217-225 and vol. 4: Pomorze, Wrocław 1962, pp. 36-41 and 195-197. Also B. Bieńkowska, H. Chamerska, Tysiąc lat ksiązi i bibliotek w Polsce, Wrocław 1992, pp. 22-23. About printing in Poland see also J. Pirożyński, Johannes Gutenberg i początki ery druku, Warszawa 2002, and about earlier period E. Potkowski, Książa rękopiśmienna w kulturze Polski, Warszawa 1984. 
ones should be condemned to be forgotten and lost? Constructing a computer and programming its work are quite different things than creating a web of references and selecting content present in them ${ }^{27}$. As in the later phase of spreading of print technology, where there were always more influence of specialists on texts editing and on their commercial use, also nowadays the progress of digitalization relies more and more on those who decide what technicians should $\mathrm{do}^{28}$. However, their position within our institutions still remains very fragile and new institutions that should preserve them - uncertain and even evanescent.

Together with a new technology of print arrived a necessity to establish a new canon - to decide what was worth printing and what should be left in manuscript, so apparently - condemned to be forgotten ${ }^{29}$. The former content of a library of a humanist consisted of the Bible and some writings of the Fathers of the Church, of some works on philosophy, scholastic theology, of mathematic writings of Euclid, the arithmetic ones by Boethius, of Ptolemaic courses of geography. There are only 5 classic poets, known by their names: Virgil, Ovid, Horace, Lucan, Statius (that's why Dante could say that he would like to become the 'sixth poet'). In the libraries of princes and monarchs one could find also chivalric literature and Provencal poetry (brought to Italy by French wives of the Viscontis). In Italy, there are also Dante, Petrarch and Boccaccio, of course. A similar situation can be seen in Spain, at least in those cities for which such research has been done (i.e. for Valence and Barcelona). In France, however, which had a lower degree of urbanization and where educational system developed later, but reading habit spread very

${ }^{27}$ H.J. Martin, op. cit., p. 214, 215; J. McGann, op. cit., p. 335, 341.

${ }^{28} \mathrm{Cf}$. P. Trovato, Su qualche programma informatico di classificazione dei testimoni, „Ecdotica” 2014, No 11, p. 105-111 and P. Italia, Filologia digitale. Fra teoria, metodologia e tecnica, „Ecdotica” 2014, No 11, p. 123.

${ }^{29}$ Cf. N. Harris (op. cit., p. 77-78) about a modern canon of what is, and will be, transmitted from the past. 
quickly, as to make up for the delay, already in the $70^{\prime}$ of $14^{\text {th }}$ century many Italian authors of vernacular and Latin works were read (i.e. De mulieribus claris in $\mathrm{French}^{30}$ ).

Changes that a traditional public expected were, however, not very big, indeed $^{31}$. An increasing demand for the ancient texts could be noticed and it was satisfied at a slow, but constant rate. Very quickly, however, quite as quickly as was burning the fire at the stake of Savonarola (who was the most often printed contemporary author in Italy!), burnt out the flame of humanistic novelties (even if some authors from the Florentine circle, such as Francesco Filelfo or Angelo Poliziano, were taking much care of publishing theirs writings by print). Different centers specialized in different kinds of prints - the legal or liturgical books, Bible copies for reading, studying or offering $^{32}$, Latin or vernacular literature, the luxury editions or scholastic 'evergreens' ${ }^{33}$, but also romances, especially the chivalric ones, written in prose or in verse. The introduction of the technology of print did not really shock the habits of those who had already been used to read. It rather formed a new class of readers. The conservatism of the aristocratic circles was considerable. More flexible was the attitude of such classes as lawyers, who used to read a lot even before the arriving of print and who already possessed books, but who limited their interests to professional subjects ${ }^{34}$.

${ }^{30}$ R. Fédou, La vie intellectuelle à Lyon avant l'apparition du livre, „Histoire et Civilisation du Livre. Nouvelles études lyonnaises", Genève 1969, pp. 20-33. The first translation to Polish of this work is very recent: $O$ stynnych kobietach, transl. P. Bańkowski, I. Grześczak, A. Szopińska, Warszawa 2013.

${ }^{31}$ H.J. Martin, op. cit., pp. 191-192; B. Richardson, Printing, Writers and Readers in Renaissance Italy, Cambridge 2004, p. 112 and ff.

${ }^{32}$ About different functions of the Bible in the incunabula epoch see K. Jensen, Printing the Bible in the Fifteenth Century. Devotion, Philology and Commerce, [in:] Incunabula and their Readers, red. idem, London 2003, pp. 118-130.

${ }^{33}$ Cf. R. Fédou, op. cit., pp. 20-21.

${ }^{34}$ One of them, Sophologium of Jacques Legrand, published by Adolf Rusch in Strasbourg before the $1^{\text {st }}$ of January 1475 , is in the fund of library of our university. 
$12 \%$ of production of Parisian presses consisted of the liturgical books, meant for the clergymen, as well as, from the 90 ' of $15^{\text {th }}$ century, of the luxury Books of Hours aspiring to be rather a status symbol than a book to be read. The Books of Hours used to imitate the manuscripts and usually were very richly illustrated by gifted artists. Luxury editions in all social contexts used to be very traditional and they remained on the margin of changes. We can see among them also writings that were published by printing presses only once. They are exciting as witnesses of a short and specific period when readers wanted, on one hand, to possess a modern object but, on the other, were still interested only in texts they were used to. Such editions let us see what was in fact interesting and important for people living in the 'old world', and look under the lining of the times from before the print. In such editions is hidden the most interesting, the most needed and useful information from the turn of times about the ways of transmission of texts, and the traditional kind of using the media.

Some illuminated copies of a tiny volume of Petrarch's verses, a famous in- $8^{\circ}$ from 1501 by Alde Manuce, can be considered as one of the most interesting examples of this misunderstanding of a new form of transmission. Its small dimensions and a new, beautiful and innovative italic font was completely deprived of the commentaries, so omnipresent and voluminoues in previous editions of the work $^{35}$. Contrary to this previous tradition of manuscripts as well as of editions both on paper and on parchment, large and empty margins were to serve the notes of a reader, considered capable of an

More about this copy see in ed. I. Wiencek, Magia i czary - „Sophologium” Jacques'a Legranda i „Fortalitium Fidei” Alonsa de Espiny jako świadectwa niepokojów religijnych. Inkunabuly ze zbiorów UKSW, [in:] Czary, alchemia, opętanie w kulturze na przestrzeni stuleci. Studia przypadków, ed. J. Pietrzak-Thébault, Ł. Cybulski, Warszawa 2015, pp. 97-118.

${ }^{35}$ M. Lowry, The World of Aldo Manuzio. Business and Scholarship in Renaissance Venice, Oxford 1979, pp. 225-227. See also M. Santoro, Storia del libro italiano, Milano 1994 (2nd ed. 2004), pp. 162-165. 
independent, individual reading and interpreting this poetry of the highest artistic level, published in the same time with an extreme care ${ }^{36}$. Yet, we can find some copies of this edition illuminated so richly, that empty margins simply do not exist anymore and the books themselves seem more like medieval luxury manuscripts than like a product of the most modern, most courageous humanistic and editorial idea of that time ${ }^{37}$.

The Parisian editors took care of a university reader and published texts that paradoxically existed already on the market: the Epistolae of pseudo-Platon (present since 1472), De Officiis of Cicero or Elegantiae linguae latinae by Lorenzo Valla. They were provided with new commentaries and introduced divisions in chapters that facilitated reading. Latin classics, such as Cicero, Salustius, Valerius Maimus, Virgil, so much present already in manuscripts, were continued to be published. The path to former scientific editions on one hand, and to the editorial differentiation on the other hand can be traced. Printers and publishers had to take care of the financial condition of their enterprises. That's why De duobus amantibus, a romance by Piccolomini, future pope Pius the Second, or his treatise about a courtly life, De curialium miseria, were published by German presses, when the first printing press on the Sorbona university went bankrupt. In France as well as in Italy, readers were interested in some less known works, still scholastic in their esprit, such as, for example, Sophologium of Jacques Legrand ${ }^{38}$.

${ }^{36}$ Cf. B. Richardson, op. cit., p. 64 in nota, 103-104, 194, 229; C.H. Clough, Pietro Bembo's Edition of Petrarch and his Association with the Aldine Press, [in:] Aldus Manutius..., op. cit., p. 47-80, especially 70-74 and 77-80; C. Dionisotti, Aldo Manuzio. Umanista e editore, Milano 1995, pp. 125-126.

${ }^{37}$ See for example a copy from the fund of National Library in Florence (Biblioteca Nazionale Centrale Firenze), RARI.Ald.3.3.35. More about it see J. Pietrzak-Thébault, Czytanie Petrarki. Teksty, prateksty, konteksty, „Studia Classica et Neolatina", vol. 10: Inter textus. Między tekstami, ed. Z. Głombiowska, Gdańsk 2013, pp. 60-63.

${ }^{38}$ See above, note 30 . 
Studies of these changes can make us understand what readers really wanted to buy. Today we usually don't know most of those titles, literature of entertainment and religious interests at the same time (Legenda Aurea or Psalter pro puero, meant for school pupils, could be considered, however, as rare exceptions). Models for these editions arrived usually from the place where they had the biggest success, i.e. from Strasbourg, Augsburg or Bale. Some texts in vernacular languages were present as well: multiplicity of chivalric and love romances, often written according to the models of lives of saints, Jesus Christ or the Holy Virgin. Some of them could reach even ten editions and probably were destined for readers who had never took a manuscript book in their hand before. This tendency was particularly strong in France, and especially in Lyons, which was a big and important center, but which remained distant from both universities and the court: 50\% of Lyons' production within 1473-1485 was in vernacular language. At the end of the century it will achieve the rate of $40 \%$, to compare with an average French rate of $30 \%$. These figures become even more significant, if we remember that Lyons was at this time the $3^{\text {rd }}$ center of printing in Europe and the seat of important book trade market ${ }^{39}$.

We should be aware, anyway, not to draw conclusions on the basis of only local production. If something was not printed, it does not necessarily mean that it was really not needed neither popular - let us see here two examples coming from Paris. The Bible to be used at universities was not printed there, because this type of books used to arrive in a sufficient amount

${ }^{39}$ See. J.D. Mellot, Pour une géographie urbaine des métiers du livre, „Histoire et Civilisation du Livre. Revue Internationale", Genève 2006, pp. 53-58; Ph. Nieto, Géographie européenne des incunables lyonnias. Deux approches cartographiques, ibidem, pp. 26-52. D. Varry, Lyons' Printers and Booksellers from the Fifteenth to the Nineteenth Century, [in:] Printed Matters. Printing, Publishing and Urban Culture in Europe in the Modern Period, ed. M. Gee, T. Kirk, Aldershot-Sydney 2002, pp. 30-34. 
from Strasbourg or Bale ${ }^{40}$. We notice also the lack of the Imitatio Christi or Sententiae of Pietro Lombardo (printed in Lyons only in 1499 and in Paris as late as in 1509, but in Strasbourg and Bale as soon as in 1468). Paris market, well provided with manuscripts and Italian or German incunabula, which are still so much present today in different library collections, didn't simply need a local printed production of these works ${ }^{41}$.

Relatively quickly, however, a fixed canon of the illustrated books was established. Albrecht Pfister (active within 1460-1464), the secretary of the bishop of Bamberg, elaborated for the first time a series of illustrated Biblical stories. Then, brothers Zainer: Günter in Augsburg and Johann in Ulm (which was the capital of playing cards production at the time!), engravers by their profession, published the second, similar series, with the wood engravings as illustrations. Following illustrated editions are: Legenda Aurea, Speculum vitae humanae, Speculum humanae salvationis, Belial (an account of an action that Satan brought up against Jesus in front of God Father), History of Troia by Colonna, fables by Esopus, De claris mulieribus by Boccacio and Gryseldis by Petrarch in its Latin translation, Melusina by Jean of Arras (this was one of very few romances known also in Poland and was printed in Polish $^{42}$ ) - in German and Latin ${ }^{43}$.

In the meantime, on the peripheries of the printed novelties, appeared another change - it was a xylographic book ${ }^{44}$. Its large production could

${ }^{40}$ K. Jensen, op. cit., pp. 128-129.

41 The trade of a manuscript book, also written in vernacular languages, developed much earlier, as its firsts testimonies come even from the $12^{\text {th }}$ century. See E. Auerbach, Język literacki $i$ jego odbiorcy w późnym antyku łacińskim i średniowie$c z u$, trans. R. Urbański, Cracow 2006, p. 264, 261 About the changes in the distribution of printing centers in Italy in the later period, see A. F. Norton, Italian Printers 1501-1520, London 1958, passim, especially pp. XIII-XXX.

${ }^{42}$ J. Krzyżanowski, Romans polski wieku XVI, Warszawa 1962, pp. 66-71.

${ }^{43}$ H.J. Martin, op. cit., p. 219.

44 That was not only a 'pre-Gutenberg' phenomenon, as M. McLuhan would like it to be. Cf. M. McLuhan, op. cit., pp. 98-100. 
decide whether it would even become a mainstream of what was published at that time, and what the large public would read in future. It was meant for a well defined target group (better than the readers of books of mobile types), whose demands were very clear and these xylographic books were produced by skilled engravers. The same engravers who published playing cards and pictures for private devotion, drew also the illustrations in editions of Ten Commandments, Exercitium super Pater Noster, Biblia Pauperum, Speculum humanae salvationis, Vitae of saints, Confessionale, Defensorium Virginis Mariae, Mirabilia Romae (guidebooks for pilgrims) and also Prophecies of Sybille about the Nativity and Crucifixion, Song of Songs, Illustrated Apocalypse $e^{45}$. The wave of popularity of the xylographic productions is parallel to the period of incunabula: it begun, more or less, in 1455 and expired just in first years of the new century. These xylographic editions soon arrived, however, into a dead end. The ideal meeting of the public's expectations, perfectly mastered technology, as well as low costs of production appeared not to be sufficient to maintain that type of prints on the crest of wave longer than for the period of these few dozens of years, which were necessary for printing press of mobile types with larger ambitions to find its place on reading market.

It was not enough, however, just to answer to the desire of entertainment and to maintain the well-established social habits (curiosity for technical novelty, devotion...). We can see how important was the role of the educated élite, having a good command of Latin based on the classical sources, but also of vernacular language, that shaped slowly as a literary language, both very useful to trace the future path of development of these new technologies that grew up mostly from seeking for a prescription to produce gold ${ }^{46}$.

${ }^{45}$ H.J. Martin, op. cit., pp. 204-206.

${ }^{46}$ Ibidem, p. 214, 179. 
Xylography used to reproduce the manuscript model, the press of mobile types created more and more its own structure, where relations between image and text were not preponderant any more, but in which the continuity of sheets constructed the process of reading. The example of a curious work, Opera nuova contemplativa, a late xylographic edition published by Giovanni Andrea Vavassore in Venice is significant. The content of a traditional 'Biblia pauperum' was put here on single sheets: every engraving on a different page, so it was not able any more to create a triangular unity: the scene of the New Testament in the centre and two biblical scenes, treated as prefigurations, on its both sides. Though, in Venice of the 20th of the $16^{\text {th }}$ century, the form of a printed book was much more common than a traditional vision. We can consider how a new medium, apparently introducing just technical novelties and improvements, in fact changes radically the way of reading. An allegory is not a natural way to perceive and to understand the world any more, it becomes something like an ornament, an 'excess', because it doesn't go together with a linear transmission of any printed text ${ }^{47}$. As a result of this process, a specialist knowledge and erudition will, unfortunately, become necessary to approach the most important texts of the past, which will become a kind of " «holy monsters»" which answer with an aloof silence to invoked questions and doubts' ${ }^{48}$.

The change of the technology of transmission leads inevitably towards changes of the vision of the text itself. In the case of the development of printing, the most crucial modifications took place as soon as one understood the need to elaborate text in an editoral way and the responsibility that it implies, and when the role of proof-readers and type-setters was recognized far from being merely a technical one ${ }^{49}$. Moreover, the spread of print developed

${ }^{47}$ Ibidem, p. 220.

${ }^{48}$ Ibidem, p. 222.

${ }^{49}$ The bibliography of this subject is very rich; I will mention only some of most interesting books: P. Trovato, Con ogni diligenza corretto. La stampa e le revisioni 
circles of public reading in vernacular languages. It contributed also to the feeling of the cultural unity of Europe - not based on Latin, as a common language any more, but built throughout the variety and different realizations of the same need of reading. Erich Auerbach considered this feeling solid enough to persist for some centuries (still he had a presentiment of its decline that turned out to be perfectly right $)^{50}$.

A question inevitably arrives: the one about the changes that will come with reading in net, where the homogeneity of printed pages and the sequence of sheets of paper are not an obligatory way of studying a document anymore and where the possibility of reproduction of documents, comparing them and correcting their different versions seems to be unlimited. Research on the manuscript sources and their understanding was (and still is) necessary for the scholars of the history of printing press. In the same way, it is necessary nowadays to study authentic documents, as well as to open archive funds ${ }^{51}$. If we deny working with an authentic document and if we totally and with no critical attitude trust to what would like to seem an electronic perfection, the research of humankind on itself and on its own past would

editoriali dei testi letterati italiani (1470-1570), Bologna 1991 (2nd ed. - Ferrara 2009), and L.D. Reynolds, N.G. Wison, Scribes and Scholars. A Guide to the Transmission of Greek and Latin Literature, Oxford 1968, (in Polish: Skrybowie i uczeni. O tym, w jaki sposób antyczne teksty literackie przetrwaty do naszych czasów, transl. P. Majewski, Warszawa 2008).

${ }^{50}$ E. Auerbach, op. cit., p. 299, 304. Yet, the crisis of humanistic studies that appeared, makes his statements very distant, and therefore even more shrewd. Cf. M. Bonfain, La filologia (romanza) al tempo della crisi degli studi umanistici, „Ecdotica” 2014, No 11, p. 171-176.

${ }^{51}$ B. Stiegler, The Fault of Epimetheus, vol. 1, Technics and Time, California 1998; S. Lerrer, Error and the Academic Self: The Scholarly Imagination, Medieval to Modern, New York 2002 (here after: J. McGann, op. cit., pp. 335-337). 
become impossible ${ }^{52}$. Every document brings also the history of its own transmission ${ }^{53}$. The memory of computers is mechanic, it is not organized in an organic way, it is deprived of a historical perspective. Though, we need this perspective ${ }^{54}$. And information is not separate from who perceives and think. The atomization of information deprived of its context, the fortuitousness and arbitrariness of presences and absences is the biggest weakness and disadvantage of the Internet ${ }^{55}$. To give a rapid and efficient instrument doesn't mean at all to influence the literary or semantic structures. When these new technological possibilities are treated in a creative way - a new genre of literature can also appear, the one existing only in a virtual space, though important enough to be already taken into consideration in the new history of literature ${ }^{56}$.

The coexistence of the documents written on paper (papyrus, parchment...) and the digitalized ones is an important problem. The first ones are needed mostly by scholars for a descriptive bibliography, scientific edition, for the theory of texts, the history of book. When creating digitalized tools we often do not think what purpose they should really serve. When preserving authentic documents we don't have to ask this question. We preserve them just because they exist, not only because they are, or rather seem to be useful, and

${ }^{52}$ About how to distinguish the terms 'document' and 'work' see H. W. Gabler, The Primacy of the Document in Editing, „Ecdotica” 2007, No 4, p. 43-56 and B. Bordalejo, Work and Document, „Ecdotica” 2013, No 10, p. 7-13 and also other essays on the subject contained of this issue of the review.

${ }^{53}$ J. McGann, op. cit., p. 336; A. Smith, Preservation, [in:] A Companion to Digital Humanities, op. cit., chap. 37.

${ }^{54}$ D. Weinberger, Too Big to Know, Basic Books, New York 2012 (here after: ibidem, p. 339, 341); J. McGann, op. cit., p. 336, 338, 344. See also K. SztopRutkowska, Cyberpamięć czyli o tym, o czym (nie)pamiętamy w Sieci, [in:] Zwrot cyfrowy $w$ humanistyce, op. cit., pp. 139-152.

${ }^{55}$ A. Serrai, op. cit., p. 21, 22.

${ }^{56}$ A. Sebastiani, Media e narrazioni a inizio millenio, „Ecdotica” 2012, No 9, pp. 461-470. 
because they have had once a certain value that we may even not know, not understand entirely. This temporary de-contextualization is merely, as Aleida Assmann says, losing a key or an address that one day, however, could be found again and lead us towards a new and unexpected interpretation ${ }^{57}$.

New products are the keys to understand the culture - we can try to understand what has already happened but we need some distance (that we actually do not have) to understand what is going on nowadays. Looking in the past can help a lot to try to understand the meaning of technological changes we experience and even foresee some consequences of them.

Let a somehow funny example demonstrate how unexpected can be the ways of the development of new technologies and possibilities they can offer us: in the $17^{\text {th }}$ century, at the time when the production of a huge amount of paper was a substantial thing for the print, France was obliged to import this good. The royal power for a long time was in difficulty to develop this production, collapsed because of the escape of many paper makers, most of protestant denomination, so reluctant to stay in the French kingdom. The revenge was long to come, but a spectacular one: in 1782, the balloon of Montgolfier brothers, entirely made out of the French paper, raised 500 meters above the earth ${ }^{58}$ !

We cannot foresee what new possibilities will appear. They will for sure astonish us, or rather our descendants. For a moment we have more questions than answers but it is important to continue to formulate queries, and the right ones. We can see some questions that appear: about the necessity of a transition period, about copyrights in a new reality, about breaking habits of readers, about creating new circles of readers... What is important is which

${ }^{57}$ A. Assmann, Canon and Archive, [in:] Cultural Memory Studies. An International Interdisciplinary Handbook, ed. A. Erll et al., Berlin-New York 2008, pp. 97-108 (here after: J. McGann, op. cit., pp. 345-346). Comp. G. C. Bowker, op. cit., p.11, 223, see also G. C. Bowker, op. cit., p.11 and 229-230.

${ }^{58}$ H.J. Martin, op. cit., p. 203. 
knowledge is required to understand a text and what we really digitalize. We need to be conscious that changing a material support is something more than a simple multiplication and is never 'innocent' (as two identical Lyons' missals would like to prove...). There are also questions about the necessity to understand a code, a commentary, a paratext of digitalized edition. They must apply to some knowledge. So, because of their high technical level, instead of spreading among a number of potential users, new technologies will be perhaps more and more limited for specialists only? Giving answers that seem evident, giving them too quickly could also be without issue (as a xylographic branch appeared to be $)^{59}$.

The paper balloon was an unexpected achievement. What will our computers, websites and databases be capable of? Forgive me to smile once again: will they fly soon?...

\section{BIBLIOGRAPHY}

Aleida Assmann, Canon and Archive, [in:] Cultural Memory Studies. An International Interdisciplinary Handbook, ed. Astrid Erll et al., Walter de Gruyter, Berlin - New York 2008.

Erich Auerbach, Język literacki i jego odbiorcy w późnym antyku łacińskim i średniowieczu, transl. Robert Urbański, Wyd. Homini, Kraków 2006 $\left(1^{\text {st }}\right.$ ed. Literaturschprache und Publikum in der lateinischen Spätantike und im Mittelalter, 1958).

Lorenzo Baldacchini, Aspettando il frontespizio: pagine bianche, occhietti e colophon nel libro antico, Sylvestre Bonnard, Milano 2004.

Howard Besser, The Past, Present, and Future of Digital Libraries, [in:] A Companion to Digital Humanities, ed. Susan Schreibmanm, Ray Siemens,

${ }^{59}$ P. Robinson, The Concept of the Work in the Digital Age, „Ecdotica” 2013, No 10 , p. 22-27. 
John Unsworth, Blackwell Publishing, Oxford 2004 (http://www.digitalhumanities.org/companion).

Barbara Bieńkowska, Halina Chamerska, Tysiąc lat ksiązki i bibliotek w Polsce, Ossolineum, Wrocław 1992.

Łukasz Bolikowski, Jan Kozłowski, Ekspansywna hybryda. Narodziny $i$ dojrzewanie humanistyki cyfrowej, „Z badań nad książką i księgozbiorami historycznymi", 2012, vol. 6.

Radosław Bomba, Narzędzia cyfrowe jako wyznaczniki nowego paradygmatu badań humanistycznych, [in:] Platforma cyfrowa dziejów książki and Zwrot cyfrowy w humanistyce, ed. Andrzej Radomski, Radosław Bomba, Lublin 2013 (http://e-naukowiec.eu/wp-content/uploads/2013/05/Zwrot_cyfrowy $\mathrm{w}$ humanistyce.pdf).

Massimo Bonfin, La filologia (romanza) al tempo della crisi degli studi umanistici, „Ecdotica”, 11 (2014), p. 170-184.

Geoffrey C. Bowker, Memory Practices in the Sciences, The MIT Press, Cambridge MA - London 2005.

Mark Byron, Archive, Text, Screen: Remediations of Modernist Manuscripts, „Ecdotica” 14 (2014), p. 56-71.

Gabriele Paolo Carosi, Da Magonza a Subiaco, l'introduzione della stampa in Italia, Bramante, Busto Arsizio, 1982[?].

Piotr Celiński, Renesansowe korzenie cyfrowego zwrotu, [in:] Platforma cyfrowa dziejów ksiażki and Zwrot cyfrowy w humanistyce, ed. Andrzej Radomski, Radosław Bomba, Lublin 2013 (http://e-naukowiec.eu/wp-content/uploads/2013/05/Zwrot cyfrowy w humanistyce.pdf).

Cecil H. Clough, Pietro Bembo's Edition of Petrarch and his Association with the Aldine Press, [in:] Aldus Manutius and Renaissance Culture, Olschki, Firenze 1998, p. 47-80.

Marilyn Deegan, Simon Tanner, Conversion of Primary Sources, [in:] A Companion to Digital Humanities, ed. Susan Schreibmanm, Ray Siemens, 
John Unsworth, Blackwell Publishing, Oxford 2004 (http://www.digitalhumanities.org/companion).

„Digital Humanities Quarterly”, http://digitalhumanities.org/dhq/vol/1/ index.htlm.

Carlo Dionisotti, Aldo Manuzio. Umanista e editore, Il Polifilo, Milano 1995.

Drukarze dawnej Polski od XV do XVIII wieku, ed. Alodia KaweckaGryczowa, vol. 1: Małopolska, Ossolineum, Wrocław 1983.

Drukarze dawnej Polski od XV do XVIII wieku, ed. Alodia KaweckaGryczowa, vol. 4: Pomorze, Ossolineum, Wrocław 1962.

Elisabeth Eisenstein, Rewolucja Gutenberga, transl. Henryk Hollender, Prószyński i S-ka, Warszawa $2004\left(1^{\text {st }}\right.$ ed. The Printing Revolution in Early Modern Europe, 1983).

René Fédou, La vie intellectuelle à Lyon avant l'apparition du livre, „Histoire et Civilisation du Livre. Nouvelles études lyonnaises”, Genève 1969.

Neil Harris, Con piede sbagliato, e con i piedi di piombo, „Ecdotica” 11 (2014), p. 73-85.

Heritage of the Printed Book Database Consortium of European Research Libraries (CERL).

\section{http://www.polona.pl.}

Incunabula quae in bibliothecis Poloniae asservantur, Ossolineum, Wrocław 1970-1993.

Incunabula Short Title Catalogue, http://www.istc.bl.uk.

Paola Italia, Filologia digitale. Fra teoria, metodologia e tecnica, „Ecdotica” 11 (2014), p. 122-130.

Kristian Jensen, Printing the Bible in the Fifteenth century. Devotion, Philology and Commerce, [in:] Incunabula and their Readers, ed. idem, The British Library, London 2003.

Julian Krzyżanowski, Romans polski wieku XVI, PIW, Warszawa 1962. 
Jerzy Kula, Zegarek historyka, Wyd. Trio, Warszawa 2001.

Histoire de l'édition française, ed. Robert Chartier, Henri-Jean Martin, Fayard - Cèrcle de la Librairie, Paris 1989, vol. 1 (1st edition 1982).

Seth Lerer, Error and the Academic Self: The Scholarly Imagination, Medieval to Modern, Columbia University Press, New York 2002.

Martin Lowry, The World of Aldo Manuzio. Business and Scholarship in Renaissance Venice, Oxford 1979 (Italian edition: Il mondo di Aldo Manuzio. Affari e cultura nella Venezia del Rinascimento, transl. P. Pavanini, Il Veltro, Roma 2000).

Magia i czary-,,Sophologium” Jacques 'a Legranda i ,, Fortalitium Fidei” Alonsa de Espiny jako świadectwa niepokojów religijnych. Inkunabuly ze zbiorów UKSW, ed. Izabela Wiencek [in:] Czary, alchemia, opętanie w kulturze na przestrzeni stuleci. Studia przypadków, ed. Joanna Pietrzak-Thébault, Łukasz Cybulski, Wyd. UKSW, Warszawa 2015.

Henri-Jean Martin, Lucien Febvre, Narodziny ksiązki, transl. Paweł Rodak, Wyd. UW, Warszawa 2014 ( $1^{\text {st }}$ edition L'apparition du livre, Paris 1958).

Jerome McGann, Philology in a New Key, „Chicago Journals” 2013, No 39/2 (Winter) (http://www.jstor.org/stable/10.1086/668528).

Jerome McGann, A New Republic of Letters. Memory and Scholarship in the Age of Digital Reproduction, Harvard University Press, Cambridge (Mass.) 2014.

Marshall McLuhan, The Gutenberg Galaxy: The Making of Typographic Man, University of Toronto Press, Toronto 1962.

Jean-Dominique Mellot, Pour une géographie urbaine des métiers du livre, „Histoire et Civilisation du Livre. Revue Internationale”, Genève 2006.

Philippe Nieto, Géographie des impressions européennes du XV siècle, [in:] Le berceau du livre imprimé : autour des incunables, ed. Pierre Aquilon, Thierry Claerr, Brepols, Turnhout 2010.

Philippe Nieto, Géographie européenne des incunables lyonnais. Deux approches cartographiques, Droz, Genève 2006. 
Frederick John Norton, Italian Printers 1501-1520: An Annotated List, with an Introduction, Bowes \& Bowes, London 1958.

Joanna Pietrzak-Thébault, Czytanie Petrarki. Teksty, prateksty, konteksty, „Studia Classica et Neolatina”, vol. 10: Inter textus. Między tekstami, ed. Zofia Głombiowska, Gdańsk 2013.

Jan Pirożyński, Johannes Gutenberg $i$ początki ery druku, PWN, Warszawa 2002.

Platforma cyfrowa dziejów książki and Zwrot cyfrowy w humanistyce, ed. Andrzej Radomski, Radosław Bomba, Lublin 2013 (http://e-naukowiec.eu/ wp-content/uploads/2013/05/Zwrot_cyfrowy_w_humanistyce.pdf).

Edward Potkowski, Książka rękopiśmienna w kulturze Polski, Ludowa Spółdzielnia Wydawnicza, Warszawa 1984.

Edward Potkowski, Rękopis a druk - przetom $w$ dziejach techniki czy $w$ dziejach cywilizacji, [in:] ed. idem, Ksiązka i pismo $w$ średniowieczu, Akademia Humanistyczna im. Aleksandra Gieysztora, Pułtusk 2006.

Leighton Durham Reynolds, N.G. Wilson, Scribes and Scholars. A Guide to the Transmission of Greek and Latin Literature, Oxford University Press, London 1968, (in Polish: Skrybowie i uczeni. O tym, w jaki sposób antyczne teksty literackie przetrwaty do naszych czasów, transl. Paweł Majewski, Wyd. UW, Warszawa 2008.

Brian Richardson, Printing, Writers and Readers in Renaissance Italy, Cambridge University Press, Cambridge 2004.

Peter Robinson, The Concept of the Work in the Digital Age, „Ecdotica” 10 (2013), p. 13-42.

Marco Santoro, Storia del libro italiano, Editrice Bibliografica, Milano 1994 (2nd ed. 2004).

Alberto Sebastiani, Media e narrazioni a inizio millenio, [in:] Itinerari nella letteratura italiana. Da Dante al web, ed.Gian mario Anselmi, Carocci, Roma 2013, pp. 463 - 471.

Alfredo Serrai, Google e bibliografia, „Bibliotheca” 2007, No 2. 
Peter Shillinsburg, Literary Documents, Texts, and Works Represented Digitally, „Ecdotica” 10 (2013), p. 76-93.

Abby Smith, Preservation, [in:] A Companion to Digital Humanities, ed. Susan Schreibmanm, Ray Siemens, John Unsworth, Blackwell Publishing, Oxford 2004 (http://www.digitalhumanities.org/companion).

Margaret M. Smith, The title-page, its early development, 1460-1510, British Library - Oak Knoll Press, London - New Castle DE 2000.

Bernard Stiegler, The Fault of Epimetheus, vol. 1, Technics and Time, Stanford University Press, Palo Alto, CA 1998.

Katarzyna Sztop-Rutkowska, Cyberpamięć czyli o tym, o czym (nie)pamiętamy w Sieci, [in:] Platforma cyfrowa dziejów ksiązki and Zwrot cyfrowy w humanistyce, ed. Andrzej Radomski, Radosław Bomba, Lublin 2013 (http://e-naukowiec.eu/wp-content/uploads/2013/05/Zwrot cyfrowy_w_humanistyce.pdf).

Alison Tara Walker, The Boundless Book: A Conversation between the Pre-modern and Post-human, „Digital Humanities Quarterly”, 2013, vol. 7 no 1 (http://digitalhumanities.org/dhq/vol/7/1/000146/000146.html).

Paolo Trovato, Con ogni diligenza corretto. La stampa e le revisioni editoriali dei testi letterati italiani (1470-1570), Il Mulino, Bologna 1991 (2nd ed. 2009).

Paolo Trovato, Su qualche programma informatico di classificazione dei testimoni, „Ecdotica” 11 (2014), p. 105-111.

Hans Tuzzi (Adriano Bon), Libro antico libro moderno. Per una storia comparata, Sylvestre Bonnard, Milano 2006.

Dominique Varry, Lyons' Printers and Booksellers from the Fifteenth to the Nineteenth Century, [in:] Printed Matters. Printing, Publishing and Urban Culture in Europe in the Modern Period, ed. Malcolm Gee, Tim Kirk, Ashgate, Aldershot - Sydney 2002.

Wolfgang Von Stromer, Au berceau des médias de masse: l'invention de l'impression des textes et des images [in:] Le berceau du livre : autour 
des incunables, éd. Frédéric Barbier, Société des Bibliophiles de Guyenne, Bordeaux 2003.

David Weinberger, Too Big to Know: Rethinking Knowledge Now That the Facts Aren't the Facts, Experts are Everywhere, and the Smartest Person in the Room is the Room, Basic Books, New York 2012.

Michelangelo Zaccarello, L'edizione critica nella nuova 'repubblica delle lettere', „Ecdotica” 2014, No 11, p. 15-25. 


\section{Transmission of Texts and New Technologies: \\ Memory or Transformation?}

The paper discusses some aspects of possibilities and dangers that new digital technologies bring in the camp of transmission of texts, especially the literary ones, and their scholar edition. While the new trends and achievements are still under discussion, a glance towards the similar situation of some 500 years ago, when printing press was introduced to replace, step by step, a manuscript communication, could be useful to understand what we experience and to foresee some ways these new technologies will probably undertake.

Keywords: text, transmission, edition, print, incunabula, digitalization. 


\section{Nowości Wydawnictwa UKSW}

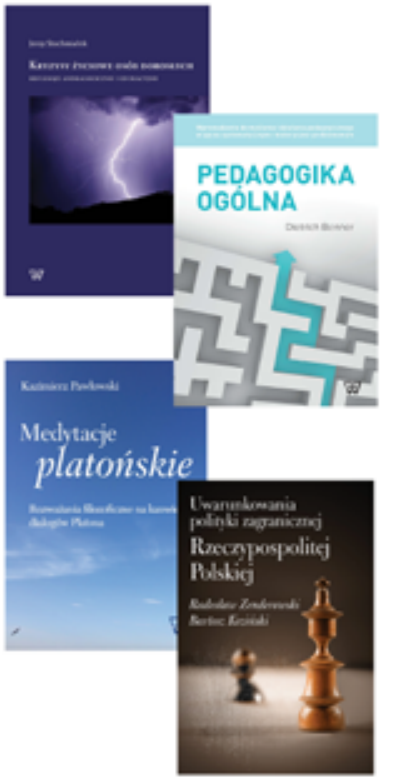

- Jerzy Stochmiałek, Kryzysy życiowe osób dorosłych

- Dietrich Benner, Pedagogika ogólna

- Kazimierz Pawłowski, Medytacje platońskie. Rozważania filozoficzne na kanwie dialogów Platona

- Bartosz Koziński, Radosław Zenderowski, Uwarunkowania polityki zagranicznej Rzeczypospolitej Polskiej

Więcej informacji na stronie: www.wydawnictwo.uksw.edu.pl 